\title{
Malignant trichilemmoma
}

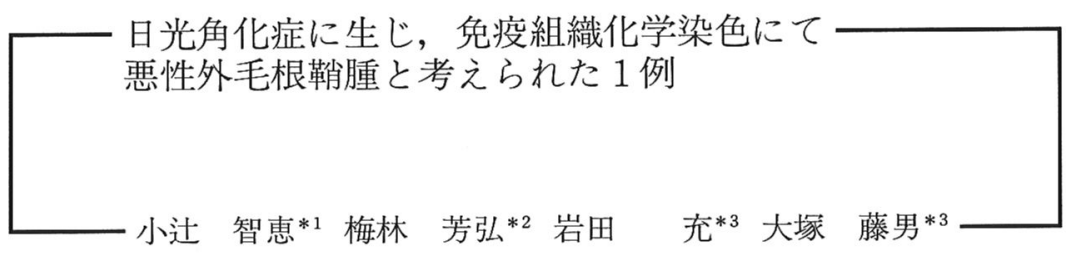

\section{Summary}

A 75-year-old woman had a nodule on her cheek. Histopathological examination revealed lobular proliferaton of clear cells in the center and basaloid in the peripheral area of the tumor. The clear cells were PAS positive, diastase sensitive. The basaloid cells showed palisading. Tumor cells were CEA (-) S-100 (-). Nuclear atypio was seen. We diagnosed it as a malignant trichilemmoma.

Immunohistochemical stining using various monoclonal anticytokeratin antibodies with formalin-fixed and paraffin-embedded block specimans was performed. All the tumor cells were positive to simple epithelial cytokeratin such as CK8, 18. Clear cells were positive to differentiated stratified epithelial cytokeratin such as CK1, and simple epithelial cytokeratin CK19. Staining pattern was different from epidemis, but similar to outer root sheath between is thmus and infundidulum.

Key words: Trichilemmoma, Cytokeratin, Immunohistochemical

\section{症例}

患 者：75歳，女性

初 診: 1996年 4 月 17 日

家族歴・既往歴：特記すべきことなし。

現病歴：10年以上前から, 右耳前部の角化性 局面に気付いた。次第に, 同部が隆起してきた ため当科を受診した。

現 病: 右耳前部に $25 \times 15 \times 1 \mathrm{~mm}$ の角化

*1 Tomoe KOTSUJI：きぬ医師会病院

*2 Yoshihiro UMEBAYASHI：日立総合病院

*3 Mitsuru IWATA, Fujio OTSUKA：筑波大学皮 膚科学教授（主任：大塚藤男教授）
性扁平隆起性局面がみられた。（図 1)。

治療および経過：日光角化症を疑い，辺縁よ

り $3 \mathrm{~mm}$ 離し脂肪織の中間で全摘，有茎皮弁形 
成術を施行した。14カ月経過した現在再発はみ られていない。

病理組織学的所見：弱拡大像では, 腫癔の表 面には錯角化・過角化がみられ，真皮中層まで 腫瘍細胞が不規則, 葉状に増殖していた（図 2 )。 腫瘍巣の辺緑は好塩基性の細胞群よりなり, 中 心に近づくにつれて細胞質の明るい細胞群に変 化していた（図 3 )。腫瘍辺縁では好塩基性の細 胞の核の栅状配列がみられた (図 4 )。腫瘍中心 部では，好酸性の豊富な細胞質をもつ大型の clear cell がみられ,これらは大型の核と明瞭な 核小体をもち，二核の細胞もみられ，異型性が みられた。clear cell の細胞質は PAS 染色にて 好酸性に染まり，ジアスターゼで消化された。

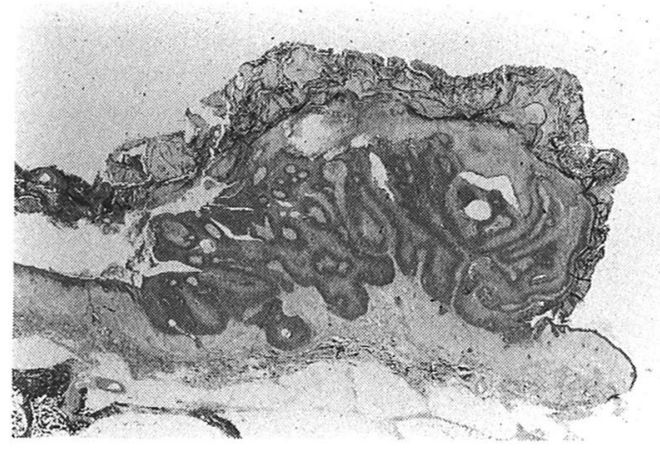

図 2. HE 染色弱拡大像

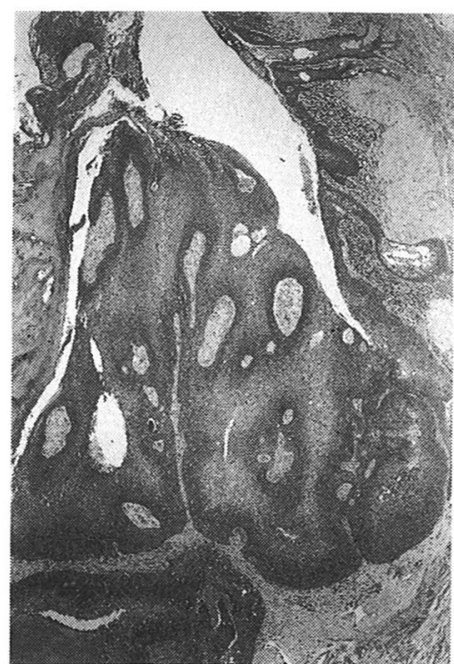

図 3.HE 染色強拡大像

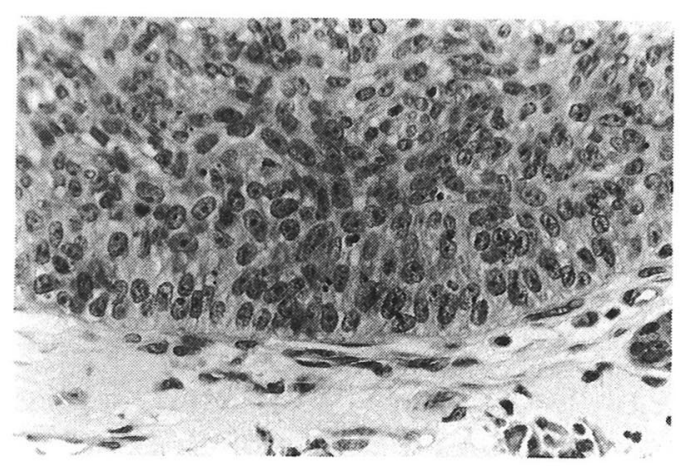

囯 4. HE 染色強拡大像

表 1. 正常皮膚組織と自験例腫瘍における免疫組織化学染色結果

\begin{tabular}{|c|c|c|c|c|c|c|c|c|c|c|c|}
\hline \multirow[t]{3}{*}{ 抗体 } & \multirow[t]{3}{*}{ 抗原 } & \multirow[t]{3}{*}{ 販売会社 } & \multicolumn{2}{|c|}{ 表皮 } & \multicolumn{5}{|c|}{ 毛組織 } & \multicolumn{2}{|c|}{ 腫瘍細胞 } \\
\hline & & & \multirow[b]{2}{*}{$\begin{array}{l}\text { 有 } \\
\text { 整 } \\
\text { 層 }\end{array}$} & \multirow[b]{2}{*}{$\begin{array}{l}\text { 基 } \\
\text { 偭 }\end{array}$} & \multicolumn{4}{|c|}{ 外毛根鞘 } & \multirow[b]{2}{*}{$\begin{array}{l}\text { 内 } \\
\text { 毛 } \\
\text { 根 } \\
\text { 鞘 }\end{array}$} & \multirow[b]{2}{*}{$\begin{array}{c}\text { Basaloid } \\
\text { cell }\end{array}$} & \multirow[b]{2}{*}{$\begin{array}{r}\text { Clear } \\
\text { cell }\end{array}$} \\
\hline & & & & & $\begin{array}{l}\text { 漏 } \\
\text { 冬 } \\
\text { 部 }\end{array}$ & $\begin{array}{l}\text { 峡 } \\
\text { 部 }\end{array}$ & $\begin{array}{l}\text { 峡 } \\
\text { 部 } \\
\text { 最 } \\
\text { 㟲 }\end{array}$ & $\begin{array}{l}\text { 変 } \\
\text { 動 } \\
\text { 部 }\end{array}$ & & & \\
\hline $34 \beta \mathrm{B} 4$ & CK1 & Enzo & + & - & + & - & - & - & - & - & + \\
\hline M20 & $\mathrm{CK} 8$ & Sigma & - & - & - & + & + & + & - & + & + \\
\hline CKB1 & CK14 & Sigma & - & + & - & + & + & + & - & - & - \\
\hline CK-E3 & CK17 & Sigma & - & - & - & + & + & + & - & + & - \\
\hline CY90 & CK18 & Sigma & - & - & - & + & + & + & - & + & + \\
\hline $\mathrm{A} 53-\mathrm{B} / \mathrm{A} 2$ & CK19 & Sigma & - & - & - & - & + & - & - & - & + \\
\hline
\end{tabular}


腫瘍細胞は CEA および S-100蛋白は陰性であ った。

腫瘍周囲の表皮は萎縮性で，基底層の細胞は 大型のクロマチンに富む核を有し，異型性がみ られた。

診 断：日光角化症局面に生じた悪性外毛根 鞘腫。

免疫組織化学染色 (表 1)：腫瘍細胞の分化の 方向を免疫組織学的に検討すめため，ホルマり ン固定パラフイン包埋標本を脱パラフィンし, トリプシンにて30分処理した後 $\mathrm{ABC}$ 法により 各種抗ケラチンモノクローナル抗体を用いて染 色した。使用した抗体，対応する抗原，正常皮 膚と自験例の腫瘍細胞における染色結果を表 1 に示す。

\section{考察}

悪性外毛根鞘腫 (malignant trichilemmoma：以下 MT) は1976年 Headington ${ }^{11} に$ 提 唱されて以来多くの報告がみられている。また, 本邦では1978年に森岡 ${ }^{2}{ }^{2}$ は外毛根鞘を発生母地 とし, 組織構築が Bowen 病に類似し毛包の組 織学的特徵を有する表皮内腫瘍であると提唱し た。自験例のように高齢者の日光ら露光部に好 発するといわれている31。

成書によると ${ }^{4)}$, 以下の組織学的特徵が示さ れている。異型性を示す外毛根鞘に類似した clear cell の増殖。細胞質にはグリコーゲンを有 し，ジアスターゼ消化性の PAS 陽性顆粒を認 める。分葉状の増殖と腫瘍辺縁の栅状配列。し ばしば外毛根鞘性角化がみられる。しかし，外 毛根鞘性角化と思われる部分が実は壞死であっ たり ${ }^{5)}$ ，有棘細胞癌でも明澄細胞がみられる事 もあることや, PAS 染色陽性になることがある など，上記の鑑別点には疑問もある。日光角化 症にも明澄細胞型といわれる病型があり，これ らとの鑑別が問題となった

光顕上典型的 MT と考えられた症例におい ても，免疫組織化学染色によるサイトケラチン
の検討により表皮と外毛根鞘漏斗部のマルピギ 一層へ分化しており Bowen 病と考えられた例 もあっだ)。

1992年 Headington は診断基準を示した れには光顕所見のみでなく免疫組織化学的所見 などによる外毛根鞘への分化の検討が加えられ た。

自験例は，外毛根鞘性角化はみられなかった ものの，腫瘍の分葉状の増殖，PAS 陽性ジアス ターゼ消化性の clear cell, 腫瘍辺縁の好塩基性 細胞の栅状配列など MT の典型例であろうと 考えられた。

そこで，各種抗ケラチンモノクローナル抗体 を用いた免疫組織化学染色を施行した。分化型 重層上皮ケラチンである CK1 を抗原とする 34 $\beta \mathrm{B} 4$ では，正常皮膚組織においては，表皮と毛 包漏斗部のマルピギー層に陽性であるが，自験 例では腫瘍中心部の clear cell のみ陽性であっ た。単層上皮ケラチンである CK8 を認識する M20 と，そのぺアであるCK18を認識する CY90では，正常皮虐においては汗腺や外毛根 鞘の峡部と変動部に陽性であるが，自験例では 両者とも腫瘍全体に陽性であった。いわゆる増 殖ケラチンといわれ，外毛根鞘に陽性である CK17 を認識する CK-E3 では basaloid cell の み陽性であった。表皮の基底層と外毛根鞘に陽 性で重層上皮ケラチンである CK14 を認識する CKB1 では，腫瘍細胞は陰性であった。単層上 皮ケラチンである CK19 を認識する A53-B/ A2 は, 外毛根鞘峡部最外層に陽性で, 有棘細胞 癌などの悪性腫瘍でも陽性であるといわれてい るが8)，自験例では clear cell に陽性であった。

以上より，自験例では表皮にはみられない単 層上皮ケラチンである CK8，18 とともに，分化 型重層上皮ケラチンである CK1 も陽性であり， 外毛根鞘の峡部と漏斗部の境界部に分化してい ると考えられた。

また，表皮内汗管腫瘍 eccrine syringofibroadenoma などとの鑑別では，自験例で陽性 であった CK1 は重層上皮ケラチンであるが,こ 
れは汗管にはみられないので9)汗管系腫瘍は否 定的であると考えた。

以上より，自験例を免疫組織化学染色も含め て悪性外毛根鞘腫と診断した。

これまでの報告例 ${ }^{10)}$ と比べると，自験例では 分化型重層上皮ケラチンである $\mathrm{CK} 1$ を抗原と する $34 \beta \mathrm{B} 4$ が陽性である点で異なっており，今 後の症例の集積による検討が必要と考えられ た。

\section{文献}

1) Headington, J. T.: Tumor of the hair follicle. Am.J. Pathol., 85 : 480-502, 1976.

2 ）森岡貞雄：前癌性毛包腫瘍。西日皮膚，40：419428, 1978.

3 ）斎田俊明, 松本祥代 : 外毛根鞘癌の疾患概念をめ ぐって。皮膚臨床，37：509-515，1995.
4) David Elder, et al. : Tumor and of the follicular infundibulum ; in Lever's Histopathology of the Skin, 8th ed, J.B. Lippincott Company, Philadelphia, 763 .

5 ）木花いづみ, 他：Trichilemmal carcinoma の例. 臨皮, $43:$ 971-974, 1989.

6 ）小辻智恵，他：いわゆる Malignant Trichilemmoma一サイトケラチンの染色パターンから被覆 表皮ないし外毛根鞘漏斗部に分化していると考之 られた症例一。西日皮膚，59：238-240，1997。

7 ) Headington, J. T. : Tricholemmal carcinoma. J. Cutan. Pathol., 19: 83-84, 1992.

8 ）小松威彦：皮膚付属器腫演の組織化学的診断。臨 皮, $44(60)$ : 552-557, 1990.

9 ) Watanabe. et al. : Immunohistochemical Analysis of Keratin Distribution in Eccrine Poroma. Am. J. Pathol, : 231-239, 1993.

10）中村勤已，他：Malignant Trichilemmoma $の 1$ 例. Skin Cancer, 12:77-80, 1997. 